\title{
Flow Cytometric Analysis of Chronic Phase Chronic Myeloid Leukemia Patients
}

Kronik Faz Kronik Miyeloid Lösemi Hastalarını Akış Sitometrik Analizi
\[ \begin{array}{r}{ }^{1} \text { Nur Oguz Davutoglu, }{ }^{1} \text { Eren Gunduz, }{ }^{1} \text { Fatih Yaman, }{ }^{2} \text { Serap Arslan, }{ }^{2} \text { Oguz Cilingir, } \\ { }^{2} \text { Sevgi Isık, }{ }^{2} \text { Beyhan Durak Aras }\end{array} \]

${ }^{1}$ Eskisehir Osmangazi University School of Medicine, Department of İnternal Medicine, Hematology,

Eskisehir, Turkey

${ }^{2}$ Eskisehir Osmangazi University School of Medicine, Department of Medical Genetics, Eskisehir, Turkey

Correspondence:

Eren GÜNDÜZ

Eskisehir Osmangazi University

School of Medicine, Department of

İnternal Medicine, Hematology,

Eskisehir, Turkey

e-mail:erengunduz26@gmail.com

\section{Abstract}

Bone marrow aspirate for morphology and cytogenetics and qualitative reverse transcriptase polimerase chain reaction on peripheral blood cells is mandatory for the diagnosis of chronic myeloid leukemia (CML). Bone marrow biopsy and fluorescence in situ hybridisation may be necessary in selected patients. Performing other tests and diagnostic procedures depends on characteristics of the individual patient. Although flow cytometry is an essential tool in the diagnosis and monitoring of many hematological malignancies, it has a limited role in CML. In this study, we evaluated the CD45 side scatter results of our CML patients at diagnosis and during follow up. Totally $56 \mathrm{CML}$ patients (22 female and 34 male) in chronic phase treated with imatinib were included. Patients were also evaluated after 8 (3-19) months follow up. Complete blood cound parameters and CD45/SSC results of the patients at diagnosis and follow up were evaluated retrospectively. The Wilcoxon $\mathrm{T}$ test was used to compare the means between the two groups. $p<0.05$ was considered statistically significant. All of them had decreased leukocyte and platelet counts. There was no difference in hemoglobin value. Comparison of CD45/SSC results at diagnosis and follow up revealed a decrease in granulocyte and blast percentages, and an increase in lymphocyte, monocyte, normoblast percentages. Complete blood counts and CD45/SSC results were not different when we divided patients into 2 groups according to being MMR positive or MMR negative. Survival of MMR positive and negative patients were also found similar. According to the results of our study, we were unable to suggest using CD45/SSC as a routine diagnostic and/or follow up tool. However, there were limitations of our study such as the limited number of patients, the variance between the time of MMR evaluation and the evaluation at only one time point. The results may change in larger studies with serial CD45/SSC analysis and with different tyrosine kinase inhibitors.

Keywords: chronic myeloid leukemia, CD45/SSC, imatinib.

Morfoloji ve sitogenetik için kemik iliği aspiratı ve periferik kan hücrelerinde kalitatif revers transkriptaz polimeraz zincir reaksiyonu, kronik miyeloid lösemi (KML) tanısı için zorunludur. Seçilmiş hastalarda kemik iliği biyopsisi ve floresan in situ hibridizasyon gerekli olabilir. Diğer testlerin ve teșhis prosedürlerinin uygulanması, bireysel hastanın özelliklerine bağlıdır. Akıs sitometrisi birçok hematolojik malignitenin tanısında ve izlenmesinde önemli bir araç olmasına rağmen, KML’de sınırlı bir rolü vardır. Bu çalışmada KML hastalarımızın tanı anında ve takip sırasındaki CD45 dağılım sonuçlarını değerlendirdik. İmatinib ile tedavi edilen kronik fazdaki toplam 56 KML hastası (22 kadın ve 34 erkek) çalışmaya dahil edildi. Hastalar ortalama 8 (3-19) aylık takipliydi. Hastaların tanı ve takipteki tam kan sayımı parametreleri ile CD45/SSC sonuçları retrospektif olarak değerlendirildi. İki grup arasındaki ortalamaları karşılaştırmak için Wilcoxon T testi kullanıldı. $\mathrm{p}<0.05$ değeri istatistiksel olarak anlamlı kabul edildi. Hepsinde lökosit ve trombosit sayıları azalmıştı. Hemoglobin değerinde farklılık görülmedi. Tanı ve takipteki CD45/SSC sonuçlarının karşılaştırılmasında granülosit ve blast yüzdelerinde azalma, lenfosit, monosit, normoblast yüzdelerinde artış saptandı. Hastaları MMR pozitif veya MMR negatif olarak 2 gruba ayırdığımızda tam kan sayımı ve CD45/SSC sonuçları farklı değildi. MMR pozitif ve negatif hastaların sağkalımı da benzer bulundu. Çalışmamızın sonuçlarına göre, CD45/SSC'nin rutin tanı ve/veya takip aracı olarak kullanılmasını öneremedik. Ancak çalışmamızın sınırlı hasta sayısı, MMR değerlendirme zamanı ile sadece bir zaman noktasındaki değerlendirme gibi kısıtlılıkları vardı. Seri CD45/SSC analizi ve farklı tirozin kinaz inhibitörleri ile yapılan daha büyük çalışmalarda sonuçlar değişebilir.

Anahtar Kelimeler:kronik miyeloid lösemi, CD45/SSC, imatinib.

Received 06.08.2021 Accepted 24.08.2021 Online published 27.08.2021 


\section{Introduction}

When chronic myeloid leukemia (CML) is diagnosed, a bone marrow aspirate is required for morphology to distinguish chronic phase (CP) from accelerated phase (AP) or blastic phase (BP) and for cytogenetics. A core biopsy may be done to evaluate the degree of fibrosis and may identify blasts not evident in the aspirate (1-3). A qualitative reverse transcriptase polimerase chain reaction (PCR) on peripheral blood cells is mandatory to identify the type of Breakpoint Cluster Region-Abelson1 (BCR-ABL1) transcripts. If a molecular assay demonstrates BCR-ABL1, but the Philadelphia $(\mathrm{Ph})$ chromosome cannot be identified by cytogenetics, Fluorescence in situ Hybridisation (FISH) is required. The diagnostic work-up is completed by physical examination, a standard biochemical profile including hepatitis B serology, cholesterol, lipase, and hemoglobin A1c values and an electrocardiogram. Performing other tests and diagnostic procedures depends on characteristics of the individual patient (4).

Several prognostic systems (Sokal, Euro, EUTOS, ELTS) including peripheral blood blasts have been used to estimate the survival risk at baseline (5-8). Blasts are usually defined morphologically.

Blood cell counts and differential cell counts are required every 2 weeks until a complete hematologic response is achieved, quantitative PCR on blood cells must be performed at least every 3 months. FISH monitoring may be needed in patients with atypical transcripts (4).

Although flow cytometry is an essential tool in the diagnosis and monitoring of many hematological malignancies, it has a limited role in CML especially in CP. In this study, we evaluated the flow cytometry (CD45 side scatter (SSC)) results of our CML patients at diagnosis and during follow up and aimed to find a role for flow cytometry in CML.

\section{Methods}

The study group comprised $56 \mathrm{CML}$ patients (22 female and 34 male) in CP treated with imatinib. Age at diagnosis was 52 (24-82) years. Patients were also evaluated after 8 (3-
19) months follow up. Treatment responses were categorized according to European Leukemia Net criteria (4). Informed consent was obtained from all patients. No additional bone marrow biopsy was needed and all tests were performed during routine diagnostic and monitoring procedures. Ethics committee approval was obtained from the Noninterventional Clinical Studies Ethics Committee of Eskişehir Osmangazi University Faculty of Medicine with the number 2020-55 on 30.12.2020.

BCR-ABL expression was quantitated using real-time quantitative reverse-transcriptase PCR according to the Europe against Cancer Protocol using ABL as a control gene. The BCR-ABL/ABL ratio was expressed as a percentage and normalized to the international scale using a correction factor established during external standardization.

Flow cytometry was performed on 50 microliter bone marrow aspirate in EDTA on Becton Dickinson flow cytometer using 20 microliter CD45FITC/CD14PE Becton Dickinson monoclonal antibodies. Further processing was done using whole blood lyse method. A total count of $1 \times 104$ cells per tube was obtained and analyzed on CD45/SSC gate. The SSC versus CD45 plots were evaluated for CD45 expression, side scatter expression, normoblasts, granulocytes, lymphocytes, monocytes and the blasts if present.. The Wilcoxon $\mathrm{T}$ test was used to compare the means between the two groups. $\mathrm{p}<0.05$ was considered statistically significant.

\section{Results}

Fifty $(89.3 \%)$ patients were still alive at the time of data collection. Causes of death were pneumonia $(\mathrm{n}=2)$, heart failure $(\mathrm{n}=1)$, colon perforation $(\mathrm{n}=1)$ and unknown in 2 patients. Sokal risk score was low in $26(46.4 \%)$, intermediate in $22(39.3 \%)$ and high in 8 $(14.3 \%)$ patients. Bone marrow biopsy revealed fibrosis in $23(41.1 \%)$ and dysplasia in $19(33.9 \%)$ patients. Bone marrow cytogenetics was evaluable in $20(35.7 \%)$ patients and revealed $46, \mathrm{XX}, \mathrm{t}(9 ; 22)(\mathrm{q} 34 ; \mathrm{q} 11)$ in 16 patients, $46, X Y, t(9 ; 22)(q 34 ; q 11)$ in 2 
patients, 46,XY,t(1;9;22) in 1 patient and parameters at diagnosis and follow up are $46, \mathrm{XY}, \mathrm{t}(9 ; 22 ; 10)$ in 1 patient. Hematologic listed in Table 1.

Table 1. Hematologic parameters at diagnosis and follow up

\begin{tabular}{|c|c|c|c|c|c|c|c|c|c|}
\hline \multirow[b]{2}{*}{ Parameter } & \multicolumn{4}{|c|}{ At diagnosis } & \multicolumn{4}{|c|}{ At follow up } & \multirow[b]{2}{*}{ p } \\
\hline & Min & Max & Mean & $\begin{array}{l}\text { Standard } \\
\text { deviation }\end{array}$ & Min & Max & Mean & $\begin{array}{l}\text { Standard } \\
\text { deviation }\end{array}$ & \\
\hline Hemoglobin (g/dl) & 7 & 16 & 11.53 & 2.06 & 8.1 & 20.9 & 12.26 & 2.01 & 0.089 \\
\hline $\begin{array}{l}\text { White blood cell } \\
\left(/ \mathrm{mm}^{3}\right)\end{array}$ & 3400 & 600000 & 82810.71 & 108511.04 & 1500 & 96000 & 8816.07 & 14254.78 & $<0.001$ \\
\hline $\begin{array}{l}\text { Absolute } \\
\left.\text { neutrophil(/mm }{ }^{3}\right)\end{array}$ & 1100 & 580000 & 73324.11 & 102233.83 & 600 & 47000 & 4317.86 & 6055.72 & $<0.001$ \\
\hline $\begin{array}{l}\text { Absolute } \\
\text { lymphocyte }\left(/ \mathrm{mm}^{3}\right)\end{array}$ & 1800 & 55000 & 5551.10 & 7731.77 & 800 & 4600 & 1736.78 & 723.04 & $<0.001$ \\
\hline $\begin{array}{l}\text { Absolute monocyte } \\
\left(/ \mathrm{mm}^{3}\right)\end{array}$ & $\mathbf{0}$ & 30300 & 2213.21 & 4074.12 & $\mathbf{0}$ & 3300 & 455 & 477.68 & $<0.001$ \\
\hline $\begin{array}{l}\text { Absolute eosinophil } \\
\left(/ \mathrm{mm}^{3}\right)\end{array}$ & $\mathbf{0}$ & 26500 & 1585.89 & 3732.14 & $\mathbf{0}$ & 900 & 158.21 & 156.33 & $<0.001$ \\
\hline $\begin{array}{l}\text { Absolute } \\
\text { basophil }\left(/ \mathbf{m m}^{3}\right)\end{array}$ & $\mathbf{0}$ & 8700 & 1211.07 & 2122.80 & $\mathbf{0}$ & 2400 & 80.18 & 321.68 & $<0.001$ \\
\hline Platelet $\left(/ \mathrm{mm}^{3}\right)$ & 34000 & 2023000 & 485928.57 & 351508.02 & 14000 & 1243000 & 236339.29 & 161803.17 & $<0.001$ \\
\hline
\end{tabular}

Major molecular response (MMR) was obtained in $25(44.6 \%)$ patients. Control bone marrow biopsies were obtained in only 26 (46.4\%) patients. Fibrosis was observed in 11
$(42.3 \%)$ and dysplasia was observed in 3 $(11.5 \%)$ patients. CD45 SSC results at diagnosis and follow up are shown in Table 2.

Table 2. CD45 SSC results at diagnosis and follow up

\begin{tabular}{|c|c|c|c|c|c|c|c|c|c|}
\hline \multirow{2}{*}{$\begin{array}{l}\text { Parameter } \\
\qquad \begin{array}{r}(\%) \\
(\mathrm{n}=56)\end{array}\end{array}$} & \multicolumn{4}{|c|}{ At diagnosis } & \multicolumn{4}{|c|}{ At follow up } & \multirow[b]{2}{*}{ p } \\
\hline & Min & Max & Mean & $\begin{array}{l}\text { Standard } \\
\text { deviation }\end{array}$ & Min & Max & Mean & $\begin{array}{l}\text { Standard } \\
\text { deviation }\end{array}$ & \\
\hline Granulocyte & 31.6 & 92 & 78.20 & 12.91 & 19.7 & 74.9 & 58.09 & 11.57 & $<0.001$ \\
\hline Lymphocyte & 0 & 32.2 & 3.82 & 50.04 & 6 & 42.1 & 17.36 & 7.92 & $<0.001$ \\
\hline Monocyte & 0 & 6.1 & 1.36 & 1.21 & 1.6 & 9.6 & 3.53 & 1.33 & $<0.001$ \\
\hline Normoblast & 0 & 47 & 8.68 & 9.60 & 4 & 39 & 12.4 & 6.66 & $<0.001$ \\
\hline Blast & 0 & 9.6 & 1.56 & 2.44 & 0 & 3.7 & 0.18 & 0.67 & $<0.001$ \\
\hline
\end{tabular}


When we divided patients into 2 groups as MMR positivite and negative, we found no difference between MMR positivity and Sokal risk groups at diagnosis $(\mathrm{p}=0.378)$.

MMR positivity was not different between the patients with fibrosis $(\mathrm{p}=0.33)$ and dysplasia $(p=0.087)$ in the bone marrow biopsy at diagnosis.
Complete blood count parameters and CD45 SSC results at diagnosis and follow up in MMR positive and negative patients are shown in Table 3 and 4.

Survival of MMR positive and negative patients was not found different (101.43 $\mp 8.42$ months vs 109.36干7.44 months) (Figure 1).

Table 3. Hematologic parameters of MMR positive and negative patients

\begin{tabular}{|c|c|c|c|c|c|c|c|c|c|}
\hline \multirow[t]{2}{*}{ Parameter } & \multicolumn{4}{|c|}{$\begin{array}{c}\text { MMR positive } \\
(\mathrm{n}=\mathbf{2 5})\end{array}$} & \multicolumn{4}{|c|}{$\begin{array}{c}\text { MMR negative } \\
(\mathrm{n}=\mathbf{3 1})\end{array}$} & \multirow[b]{2}{*}{$\mathbf{p}$} \\
\hline & Min & Max & Mean & $\begin{array}{l}\text { Standard } \\
\text { deviation }\end{array}$ & Min & Max & Mean & $\begin{array}{l}\text { Standard } \\
\text { deviation }\end{array}$ & \\
\hline Hemoglobin (g/dl) & 8.5 & 16.5 & 12.1 & 1.61 & 8.1 & 20.9 & 12.3 & 2.30 & 0.96 \\
\hline $\begin{array}{l}\text { White blood cell } \\
\left(/ \mathrm{mm}^{3}\right)\end{array}$ & 2400 & 96000 & 10556 & 18859.41 & 1500 & 55000 & 7412.9 & 9134.13 & 0.81 \\
\hline $\begin{array}{l}\text { Absolute } \\
\text { neutrophil(/mm³ })\end{array}$ & 1300 & 8700 & 3492 & 1751.89 & 600 & 47000 & 4983.87 & 7984.32 & 0.54 \\
\hline $\begin{array}{l}\text { Absolute } \\
\left.\text { lymphocyte(/mm } \mathbf{m m}^{3}\right)\end{array}$ & 800 & 4600 & 1751.6 & 808.48 & 800 & 3900 & 1724.83 & 659.68 & 0.99 \\
\hline $\begin{array}{l}\text { Absolute monocyte } \\
\left(/ \mathrm{mm}^{3}\right)\end{array}$ & 100 & 3300 & 506.4 & 608.28 & 100 & 1750 & 420 & 336.81 & 0.45 \\
\hline $\begin{array}{l}\text { Absolute eosinophil } \\
\left(/ \mathrm{mm}^{3}\right)\end{array}$ & 0 & 900 & 186.4 & 194.65 & 0 & 400 & 138 & 112.77 & 0.55 \\
\hline $\begin{array}{l}\text { Absolute } \\
\text { basophil }\left(/ \mathbf{m m}^{3}\right)\end{array}$ & 0 & 100 & 41.6 & 43.27 & 0 & 2400 & 111.29 & 431.24 & 0.181 \\
\hline Platelet (/mm³) & 14000 & 338000 & 205120 & 73341.84 & 67000 & 1243000 & 261516.12 & 205491.42 & 0.63 \\
\hline
\end{tabular}

Table 4. CD45 SSC results of MMR positive and negative patients

\begin{tabular}{|c|c|c|c|c|c|c|c|c|c|}
\hline \multirow{2}{*}{$\begin{array}{l}\text { Parameter } \\
(\%)\end{array}$} & \multicolumn{4}{|c|}{$\begin{array}{l}\text { MMR positive } \\
\quad(\mathrm{n}=25)\end{array}$} & \multicolumn{4}{|c|}{$\begin{array}{l}\text { MMR negative } \\
\quad(\mathrm{n}=31)\end{array}$} & \multirow[b]{2}{*}{ p } \\
\hline & Min & Max & Mean & $\begin{array}{l}\text { Standard } \\
\text { deviation }\end{array}$ & Min & Max & Mean & $\begin{array}{l}\text { Standard } \\
\text { deviation }\end{array}$ & \\
\hline Granulocyte & 26 & 71 & 59.06 & 10.45 & 19.7 & 74.9 & 57.3 & 12.50 & 0.77 \\
\hline Lymphocyte & 8 & 42.1 & 16.36 & 6.97 & 6 & 35.4 & 18.1 & 8.63 & 0.42 \\
\hline Monocyte & 2.1 & 9.6 & 3.6 & 1.61 & 1.6 & 6.4 & 3.46 & 1.07 & 0.66 \\
\hline Normoblast & 4 & 19.8 & 11.4 & 4.35 & 4 & 39 & 13.2 & 8.03 & 0.77 \\
\hline Blast & 0 & 1 & 0.04 & 0.2 & 0 & 3.7 & 0.28 & 0.86 & 0.27 \\
\hline
\end{tabular}




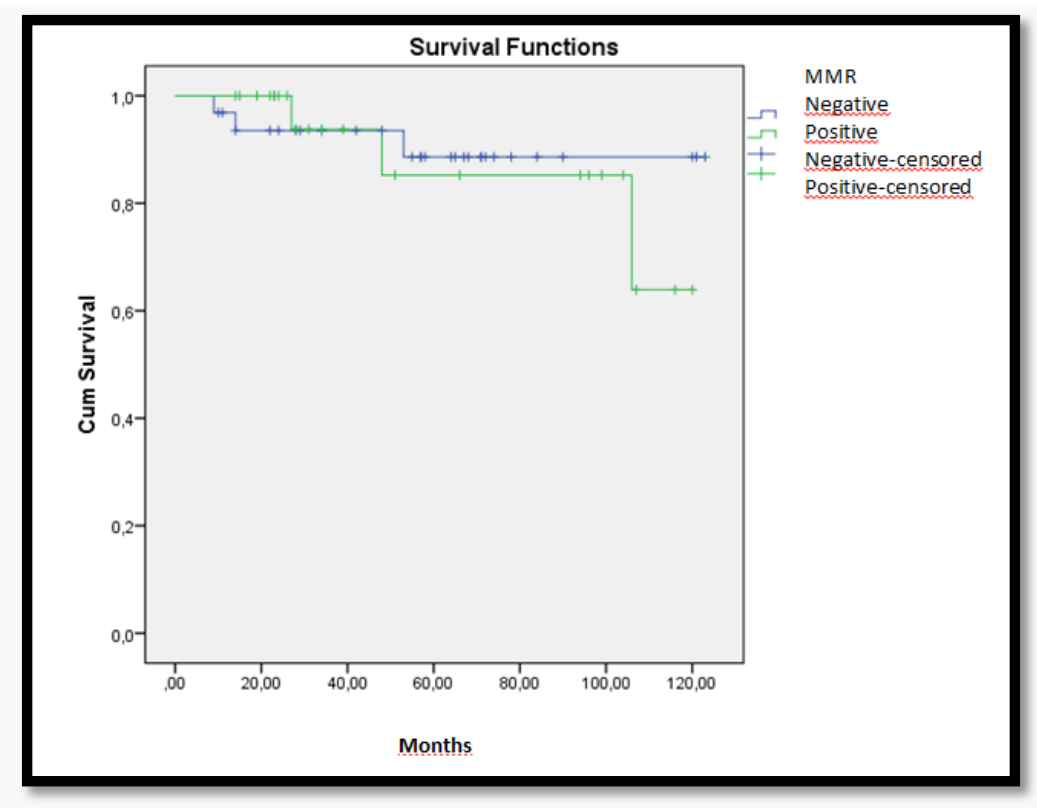

Figure 1. Survival of MMR positive and negative patients

\section{Discussion}

Flow cytometric analysis data in CML patients is scarce. Dybko et al (9) evaluated 54 CML patients and indicated that CD34+CD117+ cells must be eliminated through an apoptotic pathway to achieve optimal treatment response in CML patients.

Shima et al (10) demonstrated that granulocye-macrophage progenitor (GMP) predominance in $\mathrm{CML}$ progenitors at diagnosis and sustained expression of $\mathrm{cMpl}$ in bone marrow progenitors at 3 months may be predictive of poor outcome in children with chronic phase CML treated with imatinib.

Sun et al (11) demonstrated that flow cytometric analysis of phosphotyrosine levels is a reliable and convenient adjuvant technique for diagnosis of $\mathrm{BCR}-\mathrm{ABL}$ positive leukemias and shows promise for serial evaluation of patients undergoing treatment.

In another study (12), the results of flow cytometry analysis showed that in patients with the acquisition of resistance to imatinib the number of CD34+ cells increases in the bone marrow and peripheral blood.

Oka et al (13) showed that decrease in CD19 positive $\mathrm{B}$ lymphoid cells in the blast region is associated with a poor response to imatinib.
Cell compositions in the blast region in some patients were similar to those in myelodisplastic syndrome and healthy volunteers and they concluded that cell compositions in the blast region of bone marrow may be directly related to the proliferation of CML progenitors, leading to response to imatinib.

The flow cytometry with a CD45/SSC gate separates immature cells including blasts from other cells in bone marrow and is superior to flow cytometry with a forward scatter/sidescatter gate to identify small populations of the immature cells in bone marrow $(14,15)$.

Janssen et al (16) found that in 24 of 40 newly diagnosed CML patients residual normal CD34+CD38- stem cells could be identified by lower CD34 and CD45 expression, lower forward/sideward light scatter and by differences of lineage marker expression (CD7, CD11b and CD56) and of CD90. Patients with residual non-leukemic stem cells had lower clinical risk scores (Sokal, Euro), lower hematological toxicity of imatinib and better molecular responses to imatinib than patients without.

In this study we only used CD45/SSC gate in CP CML patients because it is widely used for 
determining leukemia phenotypes as well as detecting minimal residual disease in leukemia as a routine practice in flow cytometry laboratories at hospitals. Therefore, physicians can easily order the analysis of bone marrow in CML using flow cytometry with a CD45/SSC gate. Moreover,flow cytometry results are obtained within one or two days and data can be easily re-analysed if needed.

Firstly we compared the complete blood count parameters of patients at diagnosis and follow up. All white blood cell and platelet counts were decreased as expected and hemoglobin was not different. Comparison of CD45/SSC results at diagnosis and follow up revealed a decrease in granulocyte and blast percentages, and an increase in lymphocyte, monocyte, normoblast percentages. However complete blood counts and CD45/SSC results were not

\section{REFERENCES}

1. Buesche G, Hehlmann R, Hecker H, et al. Marrow fibrosis, indicator of therapy failure in chronic myeloid leukemia- prospective long-term results from a randomized-controlled trial. Leukemia. 2003;17:2444-53.

2. Buesche G, Ganser A, Schlegelberger B, et al. Marrow fibrosis and its relevance during imatinib treatment of chronic myeloid leukemia. Leukemia. 2007;21:2420-7.

3. Hidalgo-Lopez JE, Kanagal-Shamanna R, Quesada AE, et al. Bone marrow core biopsy in 508 consecutive patients with chronic myeloid leukemia: assessment of potential value. Cancer. 2018;124:3849-55.

4. Hochhaus A, Baccarani M, Silver RT, et al. European LeukemiaNet 2020 recommendations for treating chronic myeloid leukemia. Leukemia 2020; 34:966-84.

5. Sokal JE, Cox EB, Baccarani M, et al. Prognostic discrimination in "good-risk" chronic granulocytic leukemia. Blood. 1984;63:789-99.

6. Hasford J, Pfirrmann M, Hehlmann R, et al. A new prognostic score for survival of patients with chronic myeloid leukemia treated with interferon alfa. Writing Committee for the Collaborative CML Prognostic Factors Project Group. J Natl Cancer Inst. 1998;90:850-8.

7. Hasford J, Baccarani M, Hoffmann V, et al. Predicting complete cytogenetic response and subsequent progression-free survival in 2060 patients with CML on imatinib treatment: the EUTOS score. Blood. 2011;118:686-92.

8. Pfirrmann M, Baccarani M, Saussele S, et al. Prognosis of long-term survival considering disease-specific death in patients with chronic myeloid leukemia. Leukemia. 2016;30:48-56.

9. Dybko J, Haus O, Jaźwiec B, et al. CD117 (c-kit) expression on $\mathrm{CD} 34+$ cells participates in the different when we divided patients into 2 groups according to being MMR positive or MMR negative. Survival of MMR positive and negative patients were also found similar.

In conclusion, our results were not enough to suggest using $\mathrm{CD} 45 / \mathrm{SSC}$ as a routine diagnostic and/or follow up tool. The reasons for this result can be the limited number of patients, the variance between the time of MMR evaluation and the evaluation at only one time point. The results may change in a larger study with more CML patients, serial CD45/SSC analysis and with different tyrosine kinase inhibitors.

\section{Acknowledgement}

We would like to thank to Associate Professor Cengiz Bal from Eskisehir Osmangazi University School of Medicine Department of Statistics for the statistical analysis. cytogenetic response to imatinib in patients with chronic myeloid leukemia in the first chronic phase. Acta Haematol 2014;132:166-71.

10. Shima H, Kiyokawa N, Miharu M, et al. Flow cytometric analysis as an additional predictive tool of treatment response in children with chronicphase chronic myeloid leukemia treated with imatinib. Pediatr Blood Cancer 2017;64:264-78.

11. Sun X, Li J, Chen J, et al. Flow cytometric assay of phosphotyrosine levels in Bcr-Abl-positive chronic myelogenous leukemias: a potential prognostic marker. Ann Hematol 2009; 88:29-36.

12. Sviezhentseva IO, Perekhrestenk TP, Bilko DI, et al. Functional activity of CD34-positive cells in chronic myeloid leukemia patients with different response to imatinib therapy. Exp Oncol 2015; 37: $70-72$.

13. Oka S, Muroi K, Mori M, et al. Prediction of response to imatinib in patients with chronic myelogenous leukemia by flow cytometric analysis of bone marrow blastic cell phenotypes. Leukemia Lymphoma 2009; 50: 290-3.

14. 14.Stelzer GT, Shults KE, Loken MR. CD45 gating for routine flow cytometric analysis of human bone marrow specimens. Ann N Y Acad Sci 1993;677:265-80.

15. Borowitz MJ, Guenther KL, Shults KE, et al. Immunophenotyping of acute leukemia by flow cytometricanalysis. Use of CD45 and right-angle light scatter to gate on leukemic blasts in threecolor analysis. Am J Clin Pathol 1993;100:53440.

16. Janssen JJWM, Deenik W, Smolders KGM, et al. Residual normal stem cells can be detected in newly diagnosed chronic myeloid leukemia patients by a new flow cytometric approach and predict for optimal response to imatinib. Leukemia 2012; 26: 977-98. 